\title{
Wide Phenotypic Diversity for Resistance to Phytophthora infestans Found in Potato Landraces from Peru
}

Willmer Pérez, International Potato Center, Lima, Peru; Miriam Nahui, Universidad Nacional del Centro, Huancayo, Peru; David Ellis, International Potato Center, Lima, Peru; and Gregory A. Forbes, International Potato Center, Beijing

\begin{abstract}
Pérez, W., Nahui, M., Ellis, D., and Forbes, G. A. 2014. Wide phenotypic diversity for resistance to Phytophthora infestans found in potato landraces from Peru. Plant Dis. 98:1530-1533.

The wild and cultivated species of potato have been utilized in potato breeding to good effect but only a very small sample of the available biodiversity has been exploited. In total, 468 accessions of wild and cultivated species of potato were assessed for resistance to the oomycete pathogen Phytophthora infestans using greenhouse assays. Wide phenotypic variation for resistance was found within a species (i.e., among accessions) but not among species which, on average, were

similar. Nineteen accessions had resistance levels better than or similar to the variety Chucmarina, which is routinely used by the International Potato Center as a resistant control. Surprisingly, a number of accessions were significantly more susceptible than the susceptible control, Tomasa Condemayta. Frequency histograms of species indicated continuous variation for resistance with little evidence for functional resistance genes.
\end{abstract}

Agriculture is the economic base for rural smallholders in the developing world. Smallholder farmers at mid-elevations and highlands often have limited options for increasing their incomes in agricultural subsectors. Under these conditions, potato is an ideal crop because of its high potential productivity and high nutritive value (22). Over the last decades, potato production has increased in developing countries, where more than half of the global production now occurs (14). Unfortunately, most of this growth in potato production has come from increased land use and not increased productivity (14).

In developing countries, several diseases consistently constrain productivity of potato. One of the most important of these is potato late blight (PLB), which is caused by the oomycete pathogen Phytophthora infestans. Annual losses due to PLB, in both yield reduction and fungicide use, has been estimated to be near U.S.\$10 billion (14). PLB is present in all major areas where potato is grown (15), although disease intensity depends on local weather conditions and host plant susceptibility. In the highland tropics, PLB is particularly difficult to manage because of year-round potato production (10) and low famer capacity to understand and manage the disease (1).

PLB can generally be effectively managed with fungicides; however, many of these chemicals pose environmental or health hazards (17), particularly in developing countries where farmers spray by hand and seldom, if ever, use personal protective equipment (23). The most sustainable way to manage the disease is with host plant resistance but this strategy has had very limited success (8). Of the reasons given for this limited success, one of the most important is pathogen evolution, which leads to selection of new strains that are pathogenic on previously resistant potato varieties.

Host plant resistance against $P$. infestans can be found in several wild and native Solanum spp. $(3,7)$; however, two phenotypic expressions of host plant resistance to $P$. infestans have been described. One is associated with major genes (resistance $[R]$ genes), which confer near immunity against certain races of the pathogen (31). This resistance is referred to as vertical, qualitative, or race

Corresponding author: W. Pérez, E-mail: w.perez@cgiar.org

Accepted for publication 25 April 2014.

http://dx.doi.org/10.1094/PDIS-03-14-0306-RE

(C) 2014 The American Phytopathological Society specific. The other type of resistance, referred to as horizontal, quantitative, or race nonspecific, is believed to be based on the presence of multiple genes of relatively small effect that, in theory, render the host partially resistant to all races of the pathogen $(18,30)$. However, quantitative resistance is often masked by qualitative resistance, making selection for the former difficult. Recently, an interval scale was developed to facilitate measurement of quantitative resistance and comparison of resistance measurements across experiments (33).

In the search for more durable sources of resistance, the International Potato Center (CIP) has initiated a program to evaluate some of its 3,500 potato landraces collected from farming communities in the Andes. These potato landraces of unknown origin and age have been selected by Andean farmers over millennia for their good taste, resistance to the adverse climatic conditions of the Andes, and resistance to pests and pathogens. The objective of the present work was to quantify and, to the extent possible, characterize the phenotypic expression of resistance to $P$. infestans in 468 accessions of potato landraces from the CIP germplasm collection.

\section{Materials and Methods}

Plant material. In total, 468 Solanum accessions distributed across seven species were evaluated for resistance to $P$. infestans. One breeding line (CIP 399076.12), belonging to the CIP population B1C5 derived from Solanum tuberosum subsp. andigena, and three Peruvian varieties (Yungay, Chucmarina, and Tomasa Condemayta) with different levels of putative horizontal resistance were used as controls. At the beginning of the experiment, all materials were propagated from in vitro mother plants free of known potato pathogens to ensure a similar high level of health. Six cuttings from each accession and control were transplanted into commercial substrate (Jiffystrips, Product 300522; Jiffy Products) mixed with organic soil and sand, which had been previously steam pasteurized for $2 \mathrm{~h}$ during 2 days consecutively. The plants were grown for 45 days until preflowering stage in $16.5-\mathrm{cm}-$ diameter pots containing the above-mentioned substrate. Insecticide (Lambda-cyhalothrin) was applied to control potato flea beetles when necessary. Plants were protected with a systemic fungicide (Benomyl) for the first 15 days after transplanting. No fungicides effective against $P$. infestans were used.

Pathogen isolate. The isolate POX67 belonging to the EC-1 lineage (32), which indiscriminately attacks both wild and cultivated tuber-bearing solanaceous hosts in Peru (11), was used in the assays. The isolate was recovered from storage in liquid nitrogen 
and multiplied on tuber slices of Huayro potato (S. chaucha) at $18^{\circ} \mathrm{C}$ in a moist chamber to promote sporulation. Inoculum was prepared as described by Perez et al. (24) and Villamon et al. (32). The sporangial concentration used in each inoculation was $3 \times 10^{3}$ sporangia/ml.

Whole-plant tests. The experiments were carried out in a greenhouse in CIP's highland station at Huancayo, Peru (3,200 $\mathrm{m}$ above sea level, $11^{\circ} 56^{\prime} \mathrm{S}, 75^{\circ} 15^{\prime} \mathrm{W}$ ). The greenhouse was equipped with overhead sprinklers to ensure leaf wetness during critical times. Shade cloth was placed around the structure to keep the temperature between 15 and $20^{\circ} \mathrm{C}$. A plastic cover was placed over the plants at night to maintain high relative humidity for disease development. The plants were inoculated with the sporangial suspension until run-off with a hand-held sprayer; the absolute volume per plant ranged between 20 and $40 \mathrm{ml}$ and depended on the amount of foliage of each inoculated plant.

Owing to the large number of plants to be assessed, three assays were done; however, the same protocols were used in each assay and the environmental conditions were similar. Each plant was considered to be an experimental unit and three plants (replicates) of each genotype were inoculated. A complete set of the controls described above was used in each assay. Pots of each replicate and controls were randomized in the greenhouse for each assay.

Evaluations. The percentage of leaf area affected of each plant was evaluated three times at 2-day intervals beginning on the third day after inoculation. From these readings, the relative area under the disease progressive curve (rAUDPC) was calculated for each individual plant from the ratings of foliar infection (2). The rAUDPC values were then used to calculate susceptibility scale values for each accession, as proposed Yuen and Forbes (33). The proposed scale has ascending numbers for increasing susceptibility, and calculation of scale values requires a common susceptible control; thus, a scale value of 9 was assigned to Tomasa Condemayta, known for its susceptibility to PLB.

Data were analyzed using the Scott and Knott multiple comparison method $(P<0.05)$ after an analysis of variance (ANOVA) using the statistical program R (R Foundation for Statistical Computing).

\section{Results}

Resistance to potato late blight. Infection was severe in all three experiments, with the overall average severity (for all three assays) being $0.7,32.3$, and $83.51 \%$ for the three reading dates, respectively. There were no significant differences in scores of controls among the three assays (data not shown). A high degree of phenotypic diversity for resistance was found among the accessions tested; however, most of this variability was found within species. When resistance was assessed at the species level, the results of the ANOVAs using the scale values and considering experiments as repeated tests showed no significant differences among species and susceptible controls Tomasa Condemayta and Yungay. However, all species were significantly more susceptible than the resistant genotypes CIP 399076.12 and Chucmarina (Table 1).

Analyses of individual accessions demonstrated much greater diversity because some were more resistant than the resistant control

Table 1. Susceptibility to Phytophthora infestans of 468 accessions belonging to eight potato landrace species tested under greenhouse conditions in Huancayo, Peru

\begin{tabular}{|c|c|c|c|c|c|}
\hline Potato landraces, species, and control varieties & $\begin{array}{c}\text { Number of accessions } \\
\text { per species }\end{array}$ & Ploidy & $\begin{array}{c}\text { Scale value } \\
\text { mean }^{y}\end{array}$ & $\begin{array}{l}\text { Standard } \\
\text { deviation }\end{array}$ & $\begin{array}{l}\text { Scott Knott Test } \\
\quad(\alpha=0.05)^{\mathrm{z}}\end{array}$ \\
\hline Tomasa Condemayta & & $2 n=4 x=48$ & 9.00 & 0.37 & a \\
\hline Solanum phureja Juz. et Buk. & 124 & $2 n=2 x=24$ & 8.21 & 1.82 & a \\
\hline Yungay & & $2 \mathrm{n}=4 \mathrm{x}=48$ & 7.60 & 0.73 & a \\
\hline S. goniocalyx Juz. et Buk. & 37 & $2 n=2 x=24$ & 7.33 & 2.44 & a \\
\hline S. stenotonum Juz. et Buk. & 112 & $2 n=2 x=24$ & 7.17 & 2.07 & a \\
\hline S. tuberosum subsp. tuberosum L. & 31 & $2 n=4 x=48$ & 7.16 & 2.42 & a \\
\hline S. curtilobum Juz. et Buk. & 5 & $2 n=5 x=60$ & 6.73 & 1.90 & $\mathrm{a}$ \\
\hline S. tuberosum subsp. andigena Juz. et Buk. & 120 & $2 n=4 x=48$ & 6.49 & 2.03 & a \\
\hline S. chaucha Juz. et Buk. & 26 & $2 n=3 x=36$ & 6.40 & 1.95 & a \\
\hline S. juzepczukii Buk. & 13 & $2 n=3 x=36$ & 5.90 & 2.98 & a \\
\hline CIP 399076.12 & $\ldots$ & $2 n=4 x=48$ & 4.11 & 0.25 & $\mathrm{~b}$ \\
\hline Chucmarina & $\ldots$ & $2 n=4 x=48$ & 3.02 & 0.44 & $\mathrm{~b}$ \\
\hline Total & 468 & $\ldots$ & $\ldots$ & $\ldots$ & $\ldots$ \\
\hline
\end{tabular}

y Susceptibility scale proposed by Yuen and Forbes (33).

${ }^{\mathrm{z}}$ In the column, averages followed by the same letter belong to a common group, because they don't differ for the Scott-Knott grouping method to 5\% of significance.

Table 2. Potato landraces accessions with Phytophthora infestans susceptibility scale values less than or equal to control variety Chucmarina

\begin{tabular}{|c|c|c|c|c|c|}
\hline CIP code, accession & Collecting code & Species & Local name & Country & Scale value mean ${ }^{2}$ \\
\hline CIP 703765 & HUA 935 & Solanum chaucha Juz. et Buk. & Chaucha Cunvicana & Peru & 2.63 \\
\hline CIP 703831 & OCH 5685 & S. goniocalyx Juz. et Buk. & Pampina & Peru & 2.85 \\
\hline CIP 704270 & CUA 534 & S. goniocalyx Juz. et Buk. & Wira Pasña & Peru & 2.85 \\
\hline CIP 704414 & OCH 5272 & S. juzepczukii Buk. & Mullu Winku & Peru & 1.58 \\
\hline CIP 704777 & HJA 1238 & S. juzерсzиkii Buk. & Jancko Kaisalla & Bolivia & 2.69 \\
\hline CIP 702619 & HHCH 4932 & S. јиzерсzиkii Buk. & Jancko Kaisalla & Bolivia & 1.43 \\
\hline CIP 701310 & PPP 1310 & S. tuberosum subsp. andigena Juz. et Buk. & Chungolonga & Peru & 2.06 \\
\hline CIP 703652 & JAK 15 & S. tuberosum subsp. andigena Juz. et Buk. & Tarmeña & Peru & 3.01 \\
\hline CIP 703957 & OCH 8544 & S. tuberosum subsp. andigena Juz. et Buk. & Siwayllus & Peru & 1.66 \\
\hline CIP 704024 & OCH 9870 & S. tuberosum subsp. andigena Juz. et Buk. & Oqe Choqllo & Peru & 1.19 \\
\hline CIP 704378 & OCH 4733 & S. tuberosum subsp. andigena Juz. et Buk. & Kashpa Ploma & Peru & 2.69 \\
\hline CIP 704590 & OCH 9248 & S. tuberosum subsp. andigena Juz. et Buk. & Puka Imilla & Peru & 1.19 \\
\hline CIP 705363 & OCH 10216 & S. tuberosum subsp. andigena Juz. et Buk. & Unknown & Ecuador & 2.85 \\
\hline CIP 704176 & UACH 1046 & S. tuberosum subsp. tuberosum L. & Unknown & Chile & 1.43 \\
\hline CIP 704332 & UACH 1057 & S. tuberosum subsp. tuberosum L. & Camota & Chile & 1.39 \\
\hline CIP 704140 & OCHS 11801 & S. stenotomum Juz. et Buk. & Unknown & Bolivia & 3.01 \\
\hline CIP 705476 & CUA 286 & S. stenotomum Juz. et Buk. & Yana Cambru & Peru & 1.43 \\
\hline CIP 705554 & CUA 728 & S. stenotomum Juz. et Buk. & Kamarita Papa & Peru & 2.53 \\
\hline CIP 703446 & OCH 8852 & S. stenotomum Juz. et Buk. & Yuraq Choqllo & Peru & 1.54 \\
\hline
\end{tabular}

${ }^{\mathrm{z}}$ Susceptibility scale proposed by Yuen and Forbes (33). 
but, in addition, a number of accessions were significantly more susceptible than the susceptible control, which had been assigned a scale value of 9 . Nineteen accessions, spread across all species, had scale values equal to or less than Chucmarina (scale value $=3.02$ ) and, thus, were identified for their resistance and potential as sources of resistance for breeding (Table 2). In all, 32 were more resistant than breeding line CIP 399076.12 (scale value $=4.11$ ) and 286 accessions were more resistant than Yungay (scale value $=7.60$ ), which is the second most popular variety grown in the Peruvian highlands (20). However, 97 accessions were also more susceptible than the control Tomasa Condemayta (scale value =9.00; Fig. 1).

The distribution pattern of resistance levels was generally similar and unimodal among the potato landraces species, indicating little evidence for the presence of major $R$ genes effective against the inoculum used in the tests (Fig. 1).

\section{Discussion}

Resistance to PLB has been reported previously for some of the species tested in this study. Accessions belonging to $S$. juzepczukii (BOL 1465 and BOL 3395) had adequate levels of field resistance in studies done in Bolivia (9). Ritter et al. (27) found one landrace accession, Chimi Lucki (CIP 702305, S. juzepczukii ) with complete resistance to PLB and two accessions with partial resistance: Poluya (CIP 703421, S. stenotonum) and Camusa (CIP 703461, S. tuberosum subsp. andigena). Resistance in S. tuberosum subsp. andigena, used either directly as landrace varieties or as a resistance source in crosses, has been reported in Peru $(12,13)$ and Bolivia (9,25). Cañizares and Forbes (4) and Revelo et al. (26) reported high levels of horizontal resistance in the Ecuadorian national collection of $S$. phureja subsp. phureja Juz. \& Buk. Coca (5) found resistance to PLB in Bolivian S. phureja varieties Jaspe, Cordillera, and Chota ñawi; however, in a subsequent study, they found different levels of resistance among $S$. phureja potato (6). In Bolivia the national potato program, PROINPA, reported field resistance to $P$. infestans in $S$. tuberosum subsp. S. andigena, $S$. stenotonum and $S$. juzepczukii (16).

In the development of the scale used in this study, Yuen and Forbes (33) suggested that the value 9 should be assigned to highly susceptible control genotypes. In the scale, ascending values were used to indicate increasing susceptibility because resistance is limited at immunity and, thus, can equal a value of 0 on the scale. However, there is no known limit to susceptibility; thus, the scale allows for the occurrence of genotypes more susceptible than the control. Nonetheless, Tomasa Condemyta was given 9 in this study because it was considered extremely susceptible and the much higher levels of susceptibility found among many accessions were surprising. The reasons for this are unknown. One possibility is that, for any variety to succeed in agriculture, some level of resistance is needed, whereas many of these accessions grow in areas where PLB does not occur. As a partial test of this hypothesis, we
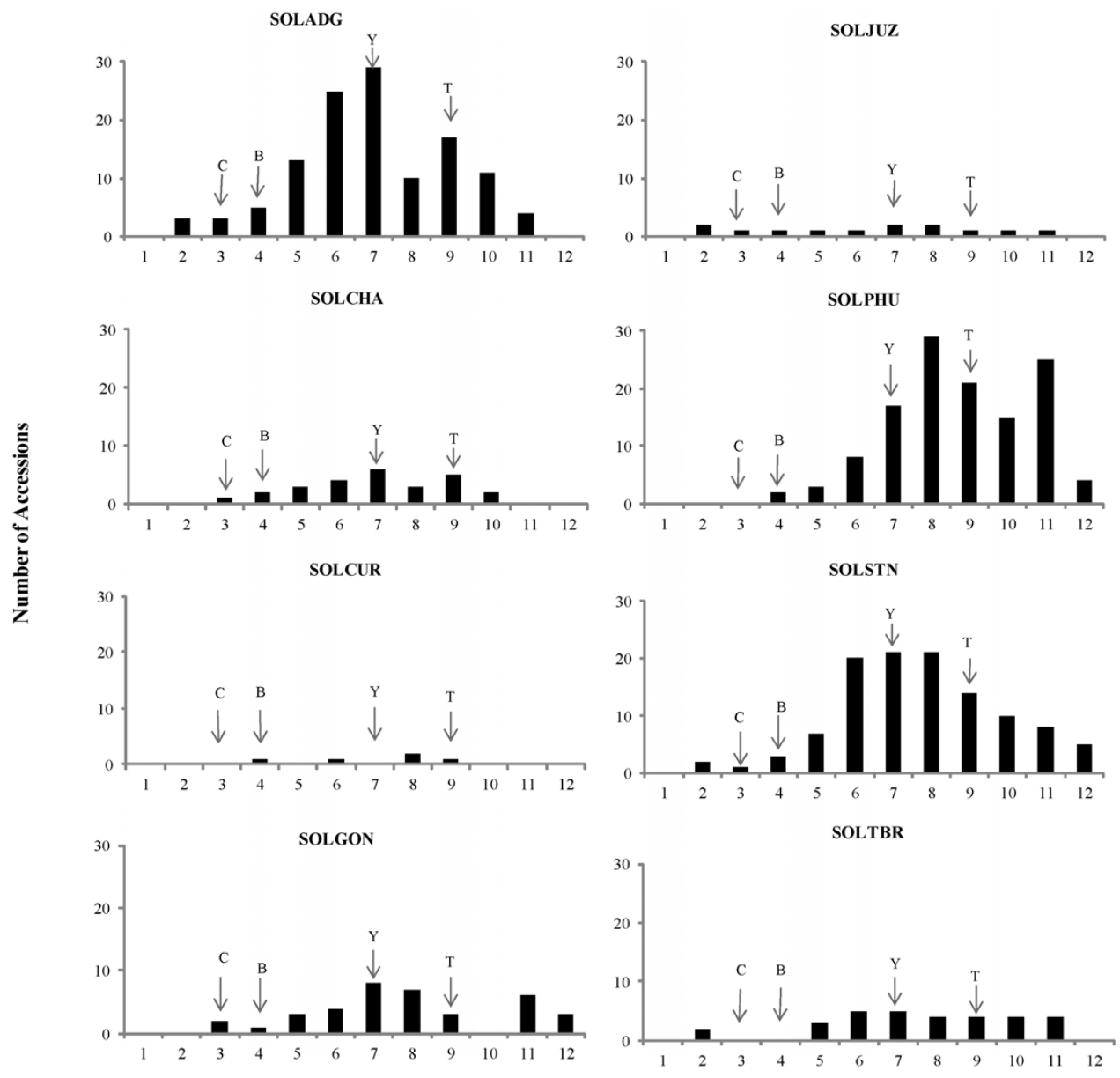

\section{Susceptibility scale values}

Fig. 1. Frequency distributions of accessions belonging to eight potato landraces for susceptibility to Phytophthora infestans tested under greenhouse conditions. Susceptibility is expressed as scale values of Yuen and Forbes (33). The position of the control varieties are indicated by arrows. Potato landraces: SOLPHU = Solanum phureja Juz. et Buk. (124 accessions), SOLGON = S. goniocalyx Juz. et Buk. (37 accessions), SOLSTN = S. stenotonum Juz. et Buk. (112 accessions), SOLCUR = S. curtilobum Juz. et Buk. (5 accessions), SOLTBR $=S$. tuberosum subsp. tuberosum L. (31 accessions), SOLADG $=$ S. tuberosum subsp. andigena Juz. et Buk. (120 accessions), SOLCHA $=$ S. chaucha Juz. et Buk. (26 accessions), and SOLJUZ = S. juzepczukii Buk. (13 accessions). Control varieties: $\mathrm{C}=\mathrm{Chucmarina}, \mathrm{B}=\mathrm{CIP}$ 399076.12, $Y=$ Yungay, and T = Tomasa Condemayta. 
evaluated the association between altitude and scale value, postulating that the most susceptible accessions may be found at altitudes where it is too cold for PLB. No significant correlation was found but there may also be many areas at lower altitudes where potato can grow, possibly with irrigation, but where conditions are also not appropriate for PLB. Regardless of the underlying biological explanation, this study added to our understanding and stretched the limits of susceptibility: what had been thought to be a 0 -to-9 scale was found here to be a 0-to-12 scale.

This study produced no clear evidence for the predictivity of geography or taxonomy because accessions with susceptibility scale values less than or equal to Chucmarina represented different countries and species: Peru $(n=13)$, Bolivia $(n=3)$, Ecuador $(n=$ $1)$, and Chile $(n=2)$; and different ploidy levels, with six diploid accessions from $S$. stenotonum $(n=4)$ and $S$. goniocalyx $(n=2)$, four triploid accessions from $S$. chaucha $(n=1)$ and $S$. juzepczuckii $(n=3)$, and nine tetraploid accessions from $S$. tuberosum subsp. andigena $(n=7)$ and $S$. tuberosum subsp. tuberosum $(n=2)$. Thus, potential sources of resistance were found in diverse locations and genetic backgrounds (Table 2). Lack of taxonomic predictivity was found to be common in a bibliographic metaanalysis done by Spooner et al. (29). Nonetheless, the accessions identified here for resistance can be used to improve PLB resistance in potato breeding populations (21).

Our analysis gave some indication of the nature of resistance in the accessions evaluated. There was little evidence of bi- or multimodality in the frequency distributions of susceptibility values (Fig. 1). Some indication of additional modes did occur on the susceptible end of the distribution (Fig. 1, SOLPHU) but there was no clear indication of a clearly distinguishable group of highly resistant accessions, as has been seen in other resistance evaluations of populations of potato genotypes $(19,28)$. In those cases, the highly resistant to near-immune phenotypes were thought to express $R$-gene-mediated resistance. We hypothesize that many of the moderately resistant phenotypes we identified were not expressing typical $R$ genes but, rather, another resistance mechanism, possibly multigenic, which is potentially durable.

\section{Acknowledgments}

We thank E. de la Torre and E. Romero for technical support and F. De Mendiburu for statistical assistance.

\section{Literature Cited}

1. Andrade-Piedra, J. L., Cáceres, P. A., Pumisacho, M., and Forbes, G. A. 2009. Humans: The neglected corner of the disease tetrahedron-Developing a training guide for resource-poor farmers to control potato late blight. Acta Hortic. 834:111-122.

2. Bonierbale, M., de Haan, S., and Forbes, A. 2007. Procedures for Evaluation Trials of Advanced Potato Clones: An International Cooperator's Guide. International Potato Center (CIP), Lima, Peru. 124 p.

3. Bradshaw, J. E., Wastie, R. L., Stewart, H. E., and Mackay, G. R. 1995. Breeding for resistance to late blight in Scotland. Pages 246-253 in: Phytophthora infestans 150. L. J. Dowley, E. Bannon, Louise R. Cooke, T. Keane, and E. O'Sullivan, eds. Boole Press, Dublin.

4. Cañizares, C. A., and Forbes, G. A. 1995. Foliage resistance to Phytophthora infestans (Mont.) de Bary in the Ecuadorian national collection of Solanum phureja ssp. phureja Juz. \& Buk. Potato Res. 38:3-10.

5. Coca, M., Tolin, L., and Montealegre, N. 2011. Resistencia a Phytophthora infestans (Mont.) de Bary de variedades de papas phurejas (Solanum phureja Juzepzuckii et Bukasov) y de especies de papas silvestres, La Paz, Bolivia. PGR Newsletter FAO-Bioversity 151:43-48.

6. Coca, M., and Tolin, I. 2013. The potato late blight caused by Phytophthora infestans Mont de Bary as selection factor of Phurejas potatoes (Solanum phureja Juz et Buk) in endemic areas of the Bolivian Andes. Am. J. Plant Sci. 4:53-58.

7. Douches, D. S., Bamberg, J. B., Kirk, W., Jastrzebski, K., Niemira, B. A., Coombs, J., Bisognin, D. A., and Felcher, K. J. 2001. Evaluation of wild Solanum species for resistance to the US-8 genotype of Phytophthora infestans utilizing a fine-screening technique. Am. J. Potato Res. 78:159165.

8. Forbes, G. A. 2012. Using host resistance to manage potato late blight with particular reference to developing countries. Potato Res. 55:205-216.

9. Gabriel, J., Coca, A., Plata, G., and Parlevliet, J. E. 2007. Characterization of the resistance to Phytophthora infestans in local potato cultivars in Bolivia. Euphytica 153:321-328.

10. Garrett, K. A., Nelson, R. J., Mundt, C. C., Chacón, G., Jaramillo, R. E., and Forbes, G. A. 2001. The effects of host diversity and other management components on epidemics of potato late blight in the humid highland tropics. Phytopathology 91:993-1000.

11. Garry, G., Forbes, G. A., Salas, A., Cruz, M. S., Perez, W., and Nelson, R. J 2005. Genetic diversity and host differentiation among isolates of Phytophthora infestans from cultivated potato and wild solanaceous hosts in Peru. Plant Pathol. 54:740-748.

12. Gastelo, M., Arcos, J., Landeo, J., and Bonierbale, M. 2010. Nuevas variedades de papa Solanum tuberosum spp. andigena (BIC5), obtenidas a través de la selección participativa por los agricultores de las comunidades del altiplano, Puno, Perú. Pages 19-20 in: Papanat 2010: Memorias. Instituto Nacional de Investigaciones Agropecuarias (INIAP), Quito, Ecuador

13. Gastelo, M., Landeo, J., Pacheco, M. A., Puente de la vega, E., and Díaz, L. 2010. Dos nuevas variedades de papa (Solanum tuberosum ssp. andigena) con resistencia horizontal al tizón tardío, seleccionadas por las comunidades altoandinas del Cusco, Perú a través de la selección varietal participativa. Pages 49-51 in: Papanat 2010: Memorias. Instituto Nacional de Investigaciones Agropecuarias (INIAP), Quito, Ecuador.

14. Haverkort, A. J., Struik, P. C., Visser, R. G. F., and Jacobsen, E. 2009. Applied biotechnology to combat late blight in potato caused by Phytophthora Infestans. Potato Res. 52:249-264.

15. Hijmans, R. J., Forbes, G. A., and Walker, T. S. 2000. Estimating the global severity of potato late blight with GIS-linked disease forecast models. Plant Pathol. 49:697-705.

16. IBTA. 1994. Catálogo Boliviano de cultivares de papa nativa. Programa de investigación de la papa (PRONIPA), Convenio IBTA-CIP-COTESU, Cochabamba, Bolivia.

17. Kromann, P., Pradel, W., Cole, D., Taipe, A., and Forbes, G. A. 2011. Use of the environmental impact quotient to estimate health and environmental impacts of pesticide usage in Peruvian and Ecuadorian potato production. Journal of Environmental Protection 2:581-591.

18. Leonards-Schippers, C., Gieffers, W., Schäfer-Pregl, R., Ritter, E., Knapp, S. J., Salamini, F., and Gebhardt, C. 1994. Quantitative resistance to Phytophthora infestans in potato: A case study for QTL mapping in an allogamous plant species. Genetics 137:67-77.

19. Lindqvist-Kreuze, H., Gastelo, M., Pérez, W., Forbes, G., De Koeyer, D., and Bonierbale, M. 2014. Phenotypic stability and genome wide association study of late blight resistance in potato genotypes adapted to the tropical highlands. Phytopathology 104:624-633.

20. Maldonado, L., Suarez, V., and Thiele, G. 2008. Estudio de la adopción de variedades de papa en zonas pobres del Perú. Documento de Trabajo. International Potato Center (CIP), Lima, Peru.

21. Mendoza, H. A., and Haynes, F. L. 1977. Inheritance of tuber initiation in tuber bearing Solanum as influenced by photoperiod. Am. Potato J. 54:243252.

22. Nunn, N., and Qian, N. 2008. Columbus's Contribution to World Population and Urbanization: A Natural Experiment Examining the Introduction of Potatoes. Harvard University, Cambridge, MA.

23. Orozco, F. A., Cole, D. C., Forbes, G. A., Kroschel, J., Wanigaratne, S., and Arica, D. 2009. Monitoring adherence to the International FAO Code of Conduct on the Distribution and Use of Pesticides-highly hazardous pesticides in central Andean agriculture and farmers' rights to health. Int. J. Occup. Environ. Health 15:255-268.

24. Perez, W., Gamboa, S., Coca, M., Raymundo, R., Hijmans, R. J., and Nelson, R. 1999. Characterization of Phytophthora infestans populations in Peru. International Potato Center (CIP), Lima, Peru.

25. Plata, G., Coca, A., and Carrasco, E. 2000. Papa nativa boliviana: Potencial para nuevas fuentes de resistencia durable al tizón de la papa (Phytophthora infestans). Pages 187-191 in: Segunda reunión boliviana sobre recursos fitogenéticos de cultivos nativos: Memorias. Fundación para la Promoción e Investigación de Productos Andinos (PROINPA). Cochabamba, Bolivia.

26. Revelo, J., Garces, S., and Andrade, J. 1997. Identification of sources of horizontal resistance to Phytophthora infestans free of major genes. CIP Circ. 23:3-1.

27. Ritter, E., Barndalla, L., López, R., and Ruiz De Galarreta, J. I. 2008. Exploitation of exotic, cultivated Solanum germplasm for breeding and commercial purposes. Potato Res. 51:301-311.

28. Sharma, B. P., Forbes, G. A., Manandhar, H. K., Shrestha, S. M., and Thapa, R. B. 2013. Determination of resistance to Phytophthora infestans on potato plants in field, laboratory and greenhouse conditions. J. Agric Sci. 5:148-157

29. Spooner, D. M., Jansky, S. H., and Simon, R. 2009. Tests of taxonomic and biogeographic predictivity: Resistance to disease and insect pests in wild relatives of cultivated potato. Crop Sci. 49:1367-1376.

30. Umaerus, V., and Umaerus, M. 1994. Inheritance of resistance to late blight. Potato Genet. 365-402.

31. Vanderplank, J. E. 1956. Horizontal (polygenic) and vertical (oligogenic) resistance against blight. Am. Potato J. 42:306.

32. Villamon, F. G., Spooner, D. M., Orrillo, M., Mihovilovich, E., Pérez, W., and Bonierbale, M. 2005. Late blight resistance linkages in a novel cross of the wild potato species Solanum paucissectum (series Piurana). Theor. Appl. Genet. 111:1201-1214.

33. Yuen, J. E., and Forbes, G. A. 2009. Estimating the level of susceptibility to Phytophthora infestans in potato genotypes. Phytopathology 99:783-786. 